Ana Galjanić

Department of Classical Philology

University of Zagreb

Ivana Lučića 3, HR-10000 Zagreb

\title{
TYPOLOGY OF ENUMERATION IN OLD IRISH, WELSH AND GREEK
}

\section{Introduction}

In this paper, I discuss poetic enumeration: an area of research which seems to have been fairly neglected both in linguistics, poetics, and classics. My main goal is to show some striking typological parallels between certain kinds of this phenomenon in Celtic and in Greek, and finally to talk about a poetic genre called priamel in Greek poetry, which, as I will try to convince you, is at least typologically, if not historically or genetically related to the Old Irish and Welsh Triads.

\section{Old Irish}

Let us first take a look at Old Irish tradition, which, I believe, is the most promising area for finding valuable parallels for Greek enumerative poetic passages ${ }^{1}$. Old Irish legal and wisdom texts (those containing precepts and proverbs on various topics), in particular deserve attention. Irish laws are precious documents preserving information about the organization and ethos of archaic Irish society, as well as documenting the early stages of the language. They are generally established to be the oldest texts within Irish tradition; although they mostly survive in $15^{\text {th }}$ and $16^{\text {th }}$ century manuscripts, the material is probably much older, originating in the $7^{\text {th }}$ and $8^{\text {th }}$ c. AD and preserving lore of earlier Irish society. It has not, however, been sufficiently noticed that these texts are particularly rich in enumerative passages and lists of various kinds. They are catalogue-like in their very nature, prose and poetic genres alike, and virtually everything in them is organised and classified according to certain parameters.

${ }^{1}$ I recall C. Watkins' remark that "classicists do not seem to be trampling each other in their haste to get at the Hittite texts" (Watkins 1998: 201). They certainly don't rush to Old Irish material, either. 
It must be mentioned that in any discussion of Old Irish texts as part of the Indo-European cultural network one is treading on slippery ground, since their age is far from being established. In my research I emphasize Old Irish law and wisdom literature, and give it somewhat of a precedence over sagas and other material: just as with Homeric texts, the issue of "orality" of the Old Irish material is closely related to the problem of its dating, and in this respect, it seems necessary to adopt one of the two existing standpoints: the nativist theory (that Old Irish literature is essentially oral in its character and preserves older pagan material) or the latinist one (which claims that Old Irish texts are a product of a literary society, reflecting primarily the early Christian world they originated in).

In my discussion of Old Irish texts, I do not side with extreme views; I do not automatically assume that any Old Irish catalogue or list is either indisputably oral, of Indo-European origin, or Medieval Christian, depending on the type of text it is transmitted in. Even in cases where genetic affiliation with Greek is hard to determine, typological comparison should yield results.

Wisdom-literature is a genre common to Celtic, Greek and Near Eastern traditions - Richard Martin has plausibly argued for Indo-European origins of some examples of a subgenre called the Speculum Principum, consisting of a list of advices to a king, found in Hesiod, Homer's Odyssey 19 and in Irish tradition ${ }^{2}$. Here are just some excerpts from Hesiod's Works and Days : advices to his brother Perses and to unspecified kings:

Ō Pérsē, sù dè taũta teōi enikáttheo thumōi (27)

'O, Perses, putlay up these things in your heart'

Taũta phulassómenoi basilēs, ithúnete múthous, dōrophágoi, skoliōn dè dikéōn epì págkhu láthesthe. (263-4)

'Keep watch against this, you princes, and make straight your judgements, you who devour bribes; put crooked judgements altogether from your thoughts.'

In Old Irish lore wisdom-literature is represented by five texts: Audacht Morainn, Tecosca Cormaic, Bríathar thecosc Con Culainn (in Serglige Con Culainn § 24-26), Tecosc Cusraid and Senbríathra Fithail. Specula are commonly written in form of a list of precepts; their nature

\footnotetext{
${ }^{2}$ Martin 1984. Pre-Christian origins of the Speculum genre have been already suggested by F. Kelly in his edition of Audacht Morainn and by Hellmann (see references in Kelly 1976: Xv).

${ }^{3}$ Transl. H. Evelyn-White 1982.
} 
can be exemplified by the structure and style of the oldest one, Audacht Morainn. The text contains several enumerative passages: a) all the precepts of a judge Morann to his foster-son Neire are introduced by the phrase apair fris 'tell him'; b) the interdependence of the king, his rightful behavior, and his subjects (§ 6-11) is expressed in a series of parallelisms with the same verb repeated in a different tense/mood: "let him X the Y, the Y will X him"; c) central paragraphs (\$12-28) list various kinds of welfare in a land that depend on the justice of a king, each preceded by repetitive is tre fir flathemon, "it is through the justice of the ruler [that]..."; d) paragraphs 32-57 are all introduced by a hortative admestar, $3^{\text {rd }}$ sg. present subjunctive of ad-midethar, 'estimates', in a formulaic admestar...asa "let him estimate X by Y"4; e) $\S 54$ lists twelve pairs of oppositions in a formulaic series to-léci $\mathrm{X}$ do $\mathrm{Y}$, "X yields to $\mathrm{Y}$ ", where $\mathrm{X}$ is invariably marked as an anti-Y, Y being the "positive" member of the pair; f) $\S 55$ is a list of fifteen virtues desirable in a king, followed by a list of ten conditions that protect kings from injustice in $\S 56$; g) § 58-62 contain an interesting classification of rulers into four categories, with ensuing description of each type.

One excerpt from the Testament of Morann exemplifies well the tone and content of Irish counterparts to Hesiodic precepts and of wisdom-literature in general:

Comath mo chosc íarmothá sund.

Sluind dó re cech bréithir,

Beir dó for cech bréithir inso sírchosc.

Comath fírinni, cotn-ofathar.

Turcbath fírinni, tan-uircéba.

Ocbath trócairi cotn-océba.

Coicleth a thúatha, cot-céillfetar

Fairtheth a thúatha, fa-rresat.

Tálgeth a thúatha, tan-áilgebat.

$$
\text { (Audacht Morainn, § 4-11) }
$$

Let him keep my advice which follows here.

Tell him before every [other] word,

Bring him with every word this lasting advice.

Let him preserve justice, it will preserve him.

Let him raise justice, it will raise him.

${ }^{4}$ Kelly (1976: xvii-xix and 1976: 42-3) notes a parallel with a Messer-series of a law text Bretha Nemed, where a list of exhortations is introduced by $2^{\text {nd }} \mathrm{sg}$. subjunctive messer ... iarna/ara "may you judge $\mathrm{X}$ by $\mathrm{Y}$ ". 
Let him exalt mercy, it will exalt him.

Let him care for his tribes, they will care for him.

Let him help his tribes, they will help him.

Let him soothe his tribes, they will soothe him. ${ }^{5}$

Since it is now generally agreed that Hesiodic didactic poetry has been introduced to Greece from the Near East, Old Irish material is a unique comparandum for assessing the value and degree of genetic versus typological affiliations in this poetic genre.

The "list-oriented" mindset of the entire Old Irish literary culture can also be illustrated by the formal categorization of the sagas. We owe the usual division into cycles to German and Irish philologists of the $19^{\text {th }}$ century, and it is very similar to the one in Greek epic tradition. However, a much older, "native" division was made by Irish monks in Medieval times, who organised the stories (scéla) into several genres according to their topic: Destructions (Togla), Cattle Raids (Tána), Wooings (Tochmarca), Battles (Catha), Feasts (Fessa), Deaths (Oitte, Aideda), Conceptions (Comperta), etc. This division is preserved in two medieval texts, one of which is a part of one of the oldest Irish manuscripts, Lebor Laignech (The Book of Leinster). This list in a form of a mnemonic alliterative poem, the fact which might point to its original oral character ${ }^{6}$ :

Togla, tána, tochmarca, catha, uatha, imrama, oitte, fessa, forbassa, echtrada et aithid 7 airggne.

'Destructions, Cattle-raids, Wooings, Battles, Hiding-tales, Voyages, Deaths, Feasts, Night-watches/-raids Adventures and Elopements and Distinctions.'

Although Old Irish sagas are generally considered to be of a later date than law- and wisdom texts, rhetoric verse passages recorded in them merit attention. For one, they are considered very archaic by many contemporary linguists and philologists - we should be aware that even the date of creation of the roscad and retoiric is disputed and is still somewhat a matter of controversy. This methodological caveat naturally need not be applied to typological approach: rhetoric passages containing enumeration are certainly good parallels for Greek lists as any.

${ }_{5}$ Translated by Kelly 1976.

${ }^{6}$ See Matasović 2004: 274. 
Thus far, I have been able to identify four types of lists in Irish lore that deserve attention inasmuch as they have counterparts in Greek poetry, most conspicuously in odes by Greek lyric poet Pindar:

I. Place-lore catalogues, such as in Dindshenchas. These are comparable and probably somehow related to lists of places in Pindar's victory odes. I am also particularly intrigued by a catalogue of seventy-three languages from which Góidel has fashioned the Irish language, found in the Lebor Gabála Érenn, section II, 11. Although this work is comparatively recent and obviously written in the Christian tradition, a version of this list appears in other, older manuscripts (most notably two $7^{\text {th }}$ century poems) and it recalls Greek enumerations of (somehow or other) important data, especially catalogues organised geographically.

II. Genealogies: these are very common and cross-culturally widespread types of lists. Irish genealogies, such as those of Leinster and Munster kings, are composed in catalogue form and should be included regardless of their relative chronology. Likewise, genealogical passages from the Lebor Gabála Érenn and certain sagas, which show intriguing parallels to Greek material, merit attention? ${ }^{7}$.

III. Dānastutis: a specific type of enumeration, which can also be said to constitute a separate genre, is praise of the gift given to a poet by his patron and known as dannastuti ('praise of the gift') in Vedic tradition; it also appears in other Indo-European literatures including Old Irish.

\section{Behaghel's Law and tripartite lists}

Let us now take a look at shorter lists, especially those containing only three entries; needless to say, every Celticist will immediately think of the Old Irish and Welsh Triads, to which I will subsequently turn after saying a word or two about a stylistic device called Behaghel's Law.

Behaghel's Law or the law of increasing members (The term das Gesetz der wachsenden Glieder was coined by the German scholar O. Behaghel. $)^{8}$, has long been recognised as one of the inherited stylistic and syntactic features of the Indo-European family of languages?. Its standard form is a list of items in which only the last one receives an epithet or an another type modifier such as the possessive genitive: "X, Y and [MODIFIER]

\footnotetext{
${ }^{7}$ A comprehensive collection of Old Irish genealogies was published in 1962 by M. A. O’Brien (ed.) as Corpus Genealogiarum Hiberniae (see O’Brien 1962).

${ }^{8}$ See Race 1990: 10 (n.2) for exact reference and other early bibliography.

${ }^{9}$ See Watkins 1995: 24 for previous bibliography.
} 
$Z^{\prime 10}$. To illustrate it, I have here chosen only several examples from various languages:

Greek:

puroí te zeiaí te id' euruphuès krĩ leukón (Hom. Od. 4.604)

'wheat and emmer and broad-growing white barley' Latin:

mihi domo familiaeque nostrae, agrum terram fundumque meum lustrandi lustrique faciendi ergo; visque duonam salutem valetudinemque mihi domo familiaeque nostrae (Cato, Suovetaurilia prayer. De agri cult. 141/3)

'to me, [to] home, to our family', '[take care of] my farm, field and land'

Old Persian:

Utā Parsaiy utā Madaiy utā aniyauvā dahayušuvā (DB 1.34-5); Utā Parsam utā Madam utā aniya dahayava (DB 1. 47-7)

'Both in Persia, in Media and in other lands', 'both Persia and Media and the other lands' (acc.)

Hittite:

na-aš-ma IGI.HI.A-i[t tk]u-it-ki a-uš-ta na-aš-ma ŠU-it ku-it-ki e-ep-t[ta] $n a-[a s ̌-m a-a s ̌-] s ̌ a-a n ~[i n-n] \mathrm{a}-r a-u$-wa-an-te-et GİR-it ku-it-ki ti-ya-at.

'if he has seen something with his eyes (IGI. HI.A-it), or taken something with his hand (ŠU-it), or trodden something with his powerful foot (innarawantet GİR-it)' (CTH 760.I.2) ${ }^{11}$

Vedic:

dyaúr, vánā, giráyo vrkșákeśāh (RV 5.41.11) ${ }^{12}$

'The sky, the forests, the tree-tressed mountains'

Old English:

Heorogār ond Hrōðgar ond Hālga til (Beowulf 61)

'Heorogar, Hrothgar and Halga the good'

Croatian:

Kome kolac, kome li konopac/ kome britku palu namjenjuje (I. Mažuranić, Smrt Smail-Age Čengića 2)

${ }^{10}$ Or in the words of C. Watkins, "X + Y + snaggle-toothed Z" (Watkins, pers. comm). For full discussion of Behaghel's Law as an Indo-European stylistic figure in Homer and numerous examples from various Indo-European traditions, see West 2004.

${ }_{11}$ Beckman 1990: 42-3; Watkins 1995, 251.

${ }^{12}$ For more "fine example[s] of Behaghel's tendency" in Vedic, see Gonda's study of the triads in the Veda (Gonda 1976: 185, 220ff). 
'To some [he gives] a pole, to some a rope, to others he gives a sharp razor'13

I go i bos, i još mu je zima (proverb)

Old Irish:

Ad-mestar arcat asa bethu bríg bánaicdib (AM 41)

'Let him estimate silver by its durability [and] value [and] white artifacts.'

These list-like examples are typically short triads with entries in form of noun-phrases. However, modifications are possible: the last constituent of a basic short triad can be enlarged by different syntactic modifiers, rather than by a simple noun-phrase: consider Croatian proverb I go, $i$ bos, $i$ još mu je zima, 'Both naked and barefoot, and he's cold in addition', where the third entry is accompanied and enlarged by an adverb.

However, entries in a tripartite list can occasionally get progressively shorter, rather than longer: in Greek poetry, such a decrescendo is found in a a triad of heroes listed in Pindar's Isthmian ode 6:

Hatis ou Pēléos aíei kléos hērōos, eudaímonos gambroũ theōn (1),

Oud' hatis Aíantos Telamōniáda (2)

Kaì patrós (3).

(Pind. Isth. 6. 25-7)

'That it does not hear tell of the fame of the hero Peleus,

the blessed son-in-law of the gods,

or of Telamonian Aias

or of his father'

The anticlimactic effect is represented iconically, creating the effect of what I call an inverted case of Behaghel's Law. This is certainly not an isolated example of syllable length being used iconically.

A similar iconic device is used in an Old Irish quatrain appropriately termed deibide baise fri tóin ('slap on the arse deibide') for its unique metrical form $\left[3^{2} 7^{2} 7^{1} 1^{1}\right]$, appearing in a dānastuti noted by Watkins in his discussion on obscure styles in Indo-European: a verse from Audacht Morainn, in which the increase in syllable length is coupled with alliteration characteristic of Old Irish poetry ${ }^{14}$ :

Ro-cúala

ní tabair cochu ar dúana

${ }^{13}$ For a detailed survey and classification of poetic figures in Serbo-Croatian folk poetry, see Zima $1988^{2}$ (reprint of the first edition from 1880).

${ }^{14}$ Watkins 1995: 187. 
do-beir a n-í as dúthaig dó

bó.

'I have heard

he gives no horses for poems;

he gives what is his nature,

a cow'

Watkins called the passage an "inverse dānastuti", and it fully deserves that title regarding both form and content: formally, the expected progressive lengthening of entries is replaced by its opposite, progressive shortening. In terms of semantics, the expected praise turns out to be a ridicule of a stingy patron. I suggest that such a "parody of dannastuti" might be hidden in fragments of Greek iambic poet Hipponax.

\section{The Priamel: Definition of the genre}

I now turn to a stylistic device, or a genre called the priamel in Greek poetic tradition, and its close relationships with tripartite lists will presently become clear.

The priamel is a stylistic device almost exclusively discussed in the context of classical, especially Greek literary tradition, with a strong focus on lyric poetry, though the term originally referred to a minor poetic genre composed in Germany from the $12^{\text {th }}$ to the $16^{\text {th }}$ centuries ${ }^{15}$. Prior to the now classical works by E. Bundy and his student W. Race, scholars considered authorities on Pindar's syntax and style, the priamel had received very little attention ${ }^{16}$. I do not intend to discuss at length stylistic features, criteria for definition or literary purpose of any of the attested instances in Pindar and other Greek authors, as valuable and extensive studies have been done

${ }^{15}$ For the history of the genre see Race 1982:1-7. The origin of the term is obscure, though it is generally considered to be a germanised form of the Latin praeambulum. The most famous author of the Medieval German priameln is the 15th century Nüremberg poet Hans Rosenplüt. These Medieval German Priameln, however, do not correspond to the definition of the priamel as understood today: these short poems consist of "a series of seemingly unrelated, often paradoxical statements which are cleverly brought together at the end, usually in the final verse" (Race 1981: 1-2).

${ }^{16}$ The two comprehensive and detailed studies on the priamel in general and on style and structure of the priamel in Pindar are respectively Race 1982 and Race 1990. In the later work, the author listed and analyzed most of the examples of list-like passages found in Pindar's odes (Race 1990: 9-40). For previous bibliography see Bundy 1962: 4-5 and Race 1982: 1-7). 
elsewhere; my main interest in the priamel stems from its essentially enumerative structure, and thus its relationship with lists and catalogues.

The article by S. Hornblower in the Oxford Classical Dictionary defines the priamel, following E. Bundy, as a "focusing device; to understand D, you have to compare it with A, B and C.. ${ }^{17}$ This is a comprehensive yet accurate enough definition in itself, for the purposes of my work, as it stresses mainly the structural criterion for identifying a passage as a priamel. A far more detailed analysis and definition can be found in Race 1982: 7-12 ${ }^{18}$. In the subsequent discussion I will often refer to Race's analysis, conclusions and definitions.

\subsection{Typological characteristics of the priamel}

The most important distinctive feature of the priamel is the "leading up to" or emphasizing the last element in a list, as priamels are built primarily on contrast and comparison, not on simple enumeration. We owe to Race the recognition of this now accepted structural and semantic property, which both acknowledges the priamel as a type of list and singles it out for its unique typology.

The extant literature on the priamel mostly focuses on the criterion of semantics rather than form and classifies the classical corpus according to either content or particular use in one author ${ }^{19}$. T. Krischel's 1974 work is the only one which attempts to systematize priamels in respect to their logical structure; he divides them into three main groups; 'focusing' ("spezificierende"), 'contrasting' ("kontrastierende" or "antithetische") and 'generalizing' ("generalisierende") ${ }^{20}$. I agree with Race's statement that, although these categories as useful in distinguishing types or relationship between the "foil" and the "climax" of the priamel, "the great problem with such a system is that individual priamels are often much more complex than these categories"21. I hope it will presently become clear why it would be impossible to establish a system based on purely internal structural distinction between various individual priamels; yet, there certainly are several general formal features which can serve as guidelines to help distinguish the priamel as a specific genre from other types of poetic enumeration. Race himself too devotes great attention to this difference and tries to establish

\footnotetext{
${ }_{17}$ OCD s.v. priamel.

${ }_{18}$ Race 1982: 1-17.

${ }^{19}$ Race 1982: 5.

${ }^{20}$ Krischer 1974 apud Race 1982: 5-7.

${ }^{21}$ Race 1982: 6.
} 
as precise criteria as possible, particularly because the genre has been so ill-defined in previous scholarship. Since I agree with his definition, which also takes into account a necessary degree of flexibility, I apply and discuss his conclusions as well as caveats wherever it is relevant.

Some of the most elaborate and famous examples of Greek priamels are found in lyric poetry; much of extant scholarship devotes particular attention to cases identified in Pindar's odes. These are usually placed in opening and closing sections, and list individual athlete's achievements, various objects or abstract qualities such as virtues. In his 1990 work, Race has identified five stylistic principles operating in Pindar's poems, in passages marked by climactic progression (priamels, hymnal addresses, catalogues):

1) increasing length

2) greater specification

3) intensification

4) increasing relevance and

5) emphatic placement.

I keep these principles in mind while looking at priamels primarily in comparison with shorter lists ${ }^{22}$. Race himself sensibly notes, "as is the case of all complex and interrelated phenomena, especially in poetics and rhetorics, where one form often shades into another, it is impossible to give a completely adequate definition of the priamel"23. This observation is particularly useful for making a distinction between priamels proper and other types of poetic enumerations: an entirely structural approach to any form of creative art would be impossible, and individual works do not easily yield to boundaries artificially imposed from the outside.

To give an example of the priamel, I quote here famous verses from Pindar's Olympian 1:

Áriston mèn húdōr, ho dè khrusòs aithómenon pũr

hate diaprépei nuktì megánoros éxokha ploútou.

Ei d'áethla garúen

Éldeai, phílon ētor,

mēket' aelíou skópei

állo thalpnóteron en haméra phaennòn

ástron erēmas di' aithéros,

${ }^{22}$ Race's criteria can certainly be applied to other attested cases of priamels in Greek poetry, outside Pindar's corpus.

${ }^{23}$ Race 1982: 7. 
mēd' Olumpías agōna phérteron audásomen.

'Best is water, while gold, like fire blazing

In the night, shines preeminent amid lordly wealth.

But if you wish to sing

Of athletic games, my hear,

Look no further than the sun

For another star shining more warmly by day

Through the empty sky,

Nor let us proclaim a contest greater than Olympia. ${ }^{24}$

I primarily focus on the synchronic description of the genre and its various types within the context of both enumerative and evaluative structures in archaic Greek poetry. By "enumerative" I refer to lists of three or more items which do not imply any comparison between these items, but simply present them in linear sequence. "Evaluative" lists, on the other hand, overtly compare the entries in terms of degree of a certain quality and establish a preference of one entry in a list over the others: syntactically, the most common grammatical categories used in last entries are the superlative or a negated comparative. It will presently become clear that the priamel corresponds to the definition of evaluative list as I understand it.

I elsewhere give an overview my own classification of poetic lists and their two types, which I call sets and series, with examples which show clear correspondences with the priamel. The typological similarities I was able to identify are based on very specific parallels in structural, pragmatic and notional patterns of the enumerative (i.e. lists) and evaluative passages (i.e. various types of priamels themselves) ${ }^{25}$.

The diachronic and comparative analysis shows the possibility of setting the priamel within larger context of common Indo-European poetic tradition. I will try to show that, through comparison with corresponding poetic structures in other cognate Indo-European traditions, the Greek priamel is not as isolated a genre as it has been assumed. This approach has to my knowledge not been applied before. It is possible to find parallels with Race's criteria for the priamel in literatures which have not previously been examined from this point of view. Again, the major starting point is to keep in mind the close formal and notional correspondences between priamels and enumerations, this time with a closer look at literatures outside Greek.

\footnotetext{
24 Transl. Race 2002.

${ }^{25}$ Galjanić 2008:143-44.
} 
We have seen that the first of Race's criteria is increasing length of entries in the priamel, which, in Race's words, "constitutes one of the most distinctive features of Pindar's style", ${ }^{26}$. It also directly corresponds to Behaghel's Law which I have already given examples of.

\section{Priamel-like poetic structures outside the Greek literary corpus: Vedic and the Welsh Triads}

As I mentioned already, the priamel as a genre has only been defined and discussed in the context of classical Greek and Latin literature, but the chances are we can find similarly constructed passages that would correspond to priamels and be identified as such in different literatures.

Such is an example from Rg Veda (RV 8.3.24), quoted by Watkins ${ }^{27}$. In line with Bundy's observation that the priamel is "the most important structural principle known to choral poetry, in particular to those forms devoted to praise", Watkins concluded that similarly constructed passages are likely to be attested in praise poetry of other Indo-European traditions ${ }^{28}$. The Vedic passage in question is a praise of the poet's patron Pākasthāman, and notionally very much in line with Pindar's priamels:

Ātmấ pitús tanứr vấsā

Ojodấ abhiáñjanam

Turîyam íd róhitasya păkasthāmānam

bhojám dātáram abravam

(RV 8.3.24)

'The soul is food, the body clothing,

Unguent gives strength;

as the fourth I name Pākasthāman,

generous giver of the bay.'

Regardless of whether we call this passage a priamel proper, or a list with its final member marked by an overt ordinal numeral, it shows a striking structural correspondence to Greek priamels. It also shows the original syntax of the ordinal number: only the fourth entry is marked by it and singled out. Furthermore, the passage is constructed according to Behaghel's Law, which is, as we have seen, a common stylistic device in priamels. The first two entries together occupy a single pāda and are of equal length (ātmá pitús [1] tanūr văsā [2]), the third entry is longer and

\footnotetext{
${ }^{26}$ See Race 1990: 9-40.

${ }^{27}$ Watkins 1995: 115.

${ }^{28}$ Watkins 1995:115 and Bundy 1962: 5.
} 
occupies the entire pāda by itself (ojodâ abhiáñjanam [3]), and the final, fourth entry extends over full two pādas (one strophe): turíyam íd róhitasya păkasthāmānam / bhojám dātấram abravam [4]. Although the final constituent is not overtly marked by a superlative, on semantic level it is certainly singled out as "the best" among all entries.

Notice also the peculiar comparison, or contrasting, of the figure of a laudandus with abstract or inanimate notions (food, clothing and unguent), rather than other human beings: it immediately recalls Pindar's $\mathrm{Ol}$. 3.42-44 which extols Theron of Acragas above water and gold. We have here a common topos employed in priamels written in honor of the poet's patron.

To go back to Celtic, one of the most important texts preserved in Welsh literature, Trioedd Ynyns Prydein ('The Welsh Triads'), lists various rulers of Britain in groups of three. Of the first four triads, three follow Behaghel's Law. For example, the second Triad:

Tri Hael Enys Prydein:

Nud Hael mab Senyllt,

Mordaf Hael mab Seruan,

Ryderch Hael mab Tudwal Tutclyt.

(Ac Arthur ehun oedd haelach no'r tri.)

(TYP 2)

'Three Generous (Noble/Victorious) Men of the Island of Britain:

Nudd the Generous, son of Senyllt,

Mordaf the Generous, son of Serwan,

Rhydderch the Generous, son of Tudwal Tudglyd.

(And Arthur himself was more generous than the three.) ${ }^{29}$

R. Bromwich comments that this triad was "for obvious reasons particularly popular among the poets" ${ }^{30}$.

Parallels with the Vedic passage, as well as with Pindar's priamels, are clear on multiple levels: the Welsh triad is encomiastic, praising one ruler above others, and it has the form of a bounded list. Syntactically, the entries listed are announced by an overt cardinal number (tri, 'three'), and are progressively longer, following Behaghel's Law in a crescendo. Finally, the fourth entry is introduced almost as an afterthought, yet it is strongly emphasised, singled out by an overt comparative haelach 'more generous':

${ }^{29}$ All translations from Welsh are from Bromwich 2006, a new and completely revised edition of her 1961 work (1978).

${ }^{30}$ Bromwich 2006: 6. 
the effect of climax is further intensified by the sense of progression at the point where repetition of the adjective in positive degree hael...hael...hael suddenly becomes a comparative haelach. Repetition of the introductory cardinal tri gives to this expanded triad a form of ring composition and includes the fourth entry as well as singling it out.

Thus, the triad is a complex bounded list with structure $((1+2+3)+4)$. More importantly, it is semantically as well as syntactically, closely comparable to Greek priamels.

Welsh triads are introduced by an overt cardinal as a rule, and more often than not follow Behaghel's Law. In some cases, either the first entry (TYP 58), the first two (TYP 37, 59, 62, 69, 70), all three (TYP 36. 53, 54, $55,83,91$ ), or only the final constituent (TYP 31) are introduced by an ordinal. Occasionally (TYP 21), a fourth entry is introduced as being "above" the previous three.

Some of the Welsh triads are particularly similar to priamels in terms of structure and semantics (e.g. TYP 66 and TYP 80 which emphasize the last entry as "more $\mathrm{x}$ than the three" by a comparative or TYP 51 which uses a superlative), while some resemble cumulative enumeration discussed above in 2.4.2. (TYP 47, 48, 49).

In regard to frequent appearance of the comparative instead of the superlative (such as we find in Greek priamels) accompanying final entries in Welsh triads, it should be noted that superlative as a morphological category began falling out of use relatively early in Insular Celtic. In Old Irish it is primarily used in artificial renderings of Latin forms, while heightened emphasis is commonly expressed by prefixes such as -ér, -der or rug- (see Thurneysen 1980: 232, § 366.3).

\section{Conclusion}

As I hope I have been able to show, the Welsh Triads and many of Old Irish texts are a) very much list-oriented, b) comparable to type of enumeration common in archaic Greek poetry, and c) share striking typological, syntactic and sometimes even semantic parallels with a peculiar Greek genre called the priamel, which has thus far been treated as an isolated stylistic phenomenon. 
References

Bergin, O., 1970: Irish Bardic Poetry (texts and translations, together with an introductory lecture, with a foreword by D. A. Binchy compiled and edited by David Greene and Fergus Kelly) ed. 3. Dublin.

Bromwich, R., 2006: Trioedd Ynys Prydein. The Triads of the Island of Britain ed. 3. Cardiff.

Bundy, E., 1962: Studia Pindarica. Berkeley.

CAlder, G., 1995: Auraicept na-n Éces; The Scholars'Primer: being the texts of the Ogham tract from the book of Ballymote and the Yellow Book of Lecan, and the text of Trefhocul from the Book of Leinster; ed. from 10 manuscripts with the introduction, translation of the Ballymote text, notes and indices ed. 2. Dublin.

Evelyn-White, H., 1982: Hesiod, The Homeric Hymns and Homerica. Cambridge, MA.

Faraone, C. A., 2005: 'Catalogues, Priamels and Stanzaic Structure in Early Greek Elegy.’ TAPA 135: 245-265.

GondA, J., 1976: Triads in the Veda. Amsterdam.

Kelly, F., 1976: Audacht Morainn. Dublin.

Kelly, F., 1988: A Guide to Early Irish Law. Dublin.

Kent, R. G., 1953: Old Persian: Grammar, Text, Lexicon. New Haven.

LAROCHE, E., 1965: Textes mythologiques hittites en transcription. Paris.

LorD, A. B., 1997: The Singer of Tales ed. 9. Cambridge, MA and London.

MACAlister, R. A. S., ED., 1939: Lebor Gabála Érenn. The Book of the Taking of Ireland. Part II. Dublin.

Mallory, J. P., ED., 1992: Aspects of the Táin. Belfast.

Martin, R., 1984: 'Hesiod, Odysseus and the Instruction of Princes.' TAPA 114: $29-48$.

Matasović, R., 1996: A Theory of Textual Reconstruction in Indo-European Linguistics. Frankfurt.

MatASOvić, R., 2004: Kamen kraljeva. Srednjovjekovne irske sage. Zagreb.

OCD $=$ Hornblower, S. AND SPAwForth, A., 2003: The Oxford Classical Dictionary ed. 3. rev. Oxford.

RACE, W. H., 1990: Style and Rhetoric in Pindar's Odes. Atlanta.

RACE, W. H., 1982: The Classical Priamel from Homer to Boethius. Leiden.

RACE, W. H., 2002: Pindar. Cambridge, MA.

Stokes, W., 1904: 'The Eulogy of Cúrói (Amra Chonrói).' Ériu 2: 1-14.

Thurneysen, R., 1980: A Grammar of Old Irish. Translated from the German by D. A. Binchy and Osborn Bergin. Revised and enlarged edition with supplement. Dublin. 
Thurneysen, R., Power, N., Dillon, M., Mulchrone, K., Binchy, D. A., Knoch, A., Ryan, J., 1936: Studies in Early Irish Law. Dublin.

Thurneysen, R., 1932: 'Colmán mac Lénéni und Senchán Torpéisc.' ZCP 19: 193-209.

WATKINS, C., 1982: 'Aspects of Indo-European poetics.' [Reprinted in Watkins 1994: 674-90.]

WatKIns, C., 1995: How to Kill a Dragon in Indo-European: Aspects of IndoEuropean Poetics. New York.

Watkins, C., 1998: 'Homer and Hittite Revisited.', in Knox, P., and Foss, C. 1998: 201-211.

West, M. L., 1997: The East Face of Helicon: West Asianic Elements in Greek Poetry and Myth. Oxford and New York.

West, M. L., 2004: 'An Indo-European Stylistic Figure in Homer.', in Bierl, A., Schmitt, A., Willi, A. 2004: 33-49.

ZiмA, L., 1988: Figure u našem narodnom pjesništvu, s njihovom teorijom ed. 2. Zagreb.

\section{Tipologija nabrajanja u staroirskome, velškome i grčkome}

\section{Sažetak}

Staroirske i velške trijade ističu se svojom repetitivnom strukturom i izraženim formulaičnim karakterom. U ovom radu uspoređuju se neki oblici enumeracije česti u keltskoj tradiciji s poetskom vrstom prijamelom posvjedočenoj samo u arhajskom grčkom. Sinkronijske osobine najlakše je objasniti iz dijakronijske perspektive. U ovom radu proučavaju se tipologija i struktura staroirskih i velških oblika nabrajanja i uspoređuju se sa slično građenim odlomcima u arhajskoj grčkoj lirici i epici.

Ključne riječi: staroirski, velški, grčki, prijamel, nabrajanje, tipologija Key words: Old Irish, Welsh, Greek, priamel, enumeration, typology 